\title{
Indonesian Students' Representation on Psychology and Social Change: Challenge for Curriculum Progression
}

\author{
Juneman Abraham, Tommy Prayoga \\ Psychology Department, Bina Nusantara University, Jakarta, Indonesia \\ Email: juneman@binus.ac.id
}

How to cite this paper: Abraham, J. and Prayoga, T. (2017) Indonesian Students' Representation on Psychology and Social Change: Challenge for Curriculum Progression. Open Journal of Social Sciences, 5, 122-135.

https://doi.org/10.4236/jss.2017.58010

Received: July 1, 2017

Accepted: August 6, 2017

Published: August 9, 2017

Copyright () 2017 by authors and Scientific Research Publishing Inc. This work is licensed under the Creative Commons Attribution International License (CC BY 4.0).

http://creativecommons.org/licenses/by/4.0/

\begin{abstract}
As a science, psychology experiences paradoxical condition. There is indeed a recognition that its applications in the educational, clinical, and industrial fields have proliferated extensively in Indonesia. However, there are criticisms that 1) psychology mimics natural science epistemology, 2) the identity of Indonesian Psychology is still in the "status quo", 3) its role in designing social change is minimal (e.g. "Mental Revolution" movement in Indonesia is considered to be more influenced by Sociology rather than Psychology proponents), 4) psychology tends to prioritize the well-being of the elite (sociallyeconomically) of society, not the poorest. This study used a qualitative descriptive approach to explore the social representation on the perceptions of university students about the contribution of psychology in inspiring them to create social change. Participants of this study were 104 Psychology students (28 males, 76 females; 101 undergraduate, 3 graduate students) in Jakarta, Banten, Westand Central Java, Indonesia. We asked them a) the reason for choosing Psychology study program, b) the meaning of social change, c) the psychological courses associated with social change, d) the social problems urgent to be managed by psychology, and e) what their own plans are in making the change. Generality and uniqueness of the participants' answers will be discussed so as to generate suggestions for psychology curriculum development that is more contextual, innovative, and empowering in Indonesia.
\end{abstract}

\section{Keywords}

Colonization, Critical, Psychology, Indonesia, Poorest, Social Change, Social Problem

\section{Introduction}

The issue of injustice and marginalization exist from time to time in any society. 
However, there are indicators that the psychology's care on it needs to be heavily improved as some people say that psychology is not aware that it "serves to maintain systems of oppression" [1] (p. 203-204). On an epistemological stance, Cruz and Sonn [1] observed that the current Western-dominated psychological studies do not possess the historical sensitivity, putting itself as the gold standard without looking at the reality of cultural variety, and even forget the dynamic of power-colonialization in the process of its development. It is not surprising that Indonesia is relatively sterile from the discussion of the politic in the education of psychology; what heavily discussed are the "mainstream" methodology and pedagogical issues. This conclusion is at least based on the readership through some recent papers written about the development of psychology scientific activities in Indonesia, e.g. [2] [3]. Meanwhile, a decade ago, Thomas Teo [4] published a book that is well-known in the psychology related field, titled "The Critique of Psychology: From Kant to Postcolonial Theory". In the book, he presented some of the most critical arguments based on historiographical literature to show that the mainstream psychology has dominated the social construction of scientific truth. However, he did not only present the problem but also sophisticated solutions for psychologists and educators to 1) not lean away from the political process, 2) keep putting the process in the consciousness, 3) accept the good politics, and 4) carry out actions to influence the process.

The ability to affect the political process is compatible with the psychology's mission to provide sustainable well-being in all level of society. One of the missions is to advocate and voice the opinion of the unheard minority and liberate the marginalized. From a psychological point of view, it can be achieved only through the effort to dismantle seven barriers, i.e. between 1) various constructed social identities, 2) the "personal" and the "cultural", 3) self and others, 4) general/novice and specialized/expert, 5) subject and object, 6) "traditional" and "modern", as well as 7) psychological vs. natural and other social sciences [1] [4].

In Indonesia, the discrepancies of distribution of psychology's roles and services are displayed back in 2012's discourses during mitigation moments of an airplane accident in a mountain. After the airplane had plummeted in the mountain, Indonesian Psychological Association offered free psychological counseling, guidance, and therapy as services for the families of the victims [5]. Without any means of cynicism, some members of the psychology community questioned the association's action that has not been being carried out also towards the other poorest societies in Indonesia, to solve social problems surrounding them. They suspected that factors such as high media coverage and society interest might contribute to the decision. For example, Suharto [6] stated:

"All this week the TV is full of tragedy [...] news and very intensive ... And I agree the effect of the media is very big! Because for me, there is another tragedy that personally no less thrilling ... but might be forgotten, even be intentionally forgotten ... 'Where were you and what were you doing on 13-14 May 1998?' ... 
Remember ... there's a black history of Indonesia ... (Remember that) The present is shaped by an understanding of the past. Today does not appear by itself."

In addition, at that time, Professor Koentjoro of Universitas Gadjah Mada, Yogyakarta, Indonesia, in the context of composition/drafting of standard operating procedure for crisis/disaster, reminded the psychology community that "Wealthy people tend to have more access to and to receive more help than the poor" [7]. What they are trying to find out is the answer whether psychologically related services by psychology practitioners in Indonesia are leaned towards the well-established individuals.

To eradicate the suspicion, there needs to be a "decolonization" action. Decolonization means giving attention to minority psychology, and take part in the fight against "colonial mentality"-that gives positive attributes towards the well-known and well-established group in the society while ignoring their counterparts in the lower social level, physically and psychologically [8]. Decolonization does not allow the inferiors in the society to be positioned as the outsider and the unimportant at will. Western psychology, in one hand, ignores the reality of the discrepancies presented above. "Psychology without context" is salient, and as Abraham and Rufaedah [9] mentioned, this "psychologization" process disregard the subjectivity and relational dimension in the human science. Cognition, affection, and conation of humans are seen as the dynamic of intra-psychic that is even going to be reduced as simple natural and neural processes. Meanwhile, in the basic reality, political and nurtural processes clearly affect the psyche of the individual and the society.

Due to the reason above, we have to realize that the psychology research agenda (that will eventually affect the psychology curriculum) in Indonesia must constantly be monitored, so the chance of being alienated from the critical and immediate societal issue in Indonesia could be weakened. The methodology of research that is urgent to be developed here is the "action research" [10]. The assumption of cognitive psychology is challenged. It is not the duality between the nature and the man nor processes dwelling in the man's head that matters but instead "a practical engagement between an organism and its environment" [10] (p. 26). The psychological explanation that uses the mechanism paradigm that favors parsimony also will not be viable, as it needs to be complemented with the connectionism paradigm that appreciates complexity.

The question that we ask in Indonesia is "When the 'critical wave' hit and provide such 'enlightenment' to the psychology world; how big is the impact toward the psychology curriculum?" Critical psychology should be beneficial in Indonesia. With a wide range of cultural and economic diversity, various social problems should be expected. Indonesia has a great potential to be a "giant laboratory" for the critical social psychology. This laboratory can and should be expanded through the three pillars of the higher education in Indonesia ("Tri Dharma PerguruanTinggi"), i.e. 1) Teaching and Education, 2) Research and 
Publication, and 3) Community Development. Regarding Teaching or Educating, psychology curriculum should not consist of only theoretical and subject matters compositions, but also activities to achieve the ultimate mission of psychology. The ones who involve in the activity are the teachers and students. Therefore, before we develop the critical psychology curriculum, we must first uncover the baseline of understanding and belief among them about the critical psychology. For example, we can explore the belief of the student as academics about the ability of psychology to initiate social change.

Their belief and efficacy are important because it holds true to their value. Value is something important that is worth to fight for and achieve. Critical psychology-unlike mainstream psychology-sees science as a concept that is not without value [11]. There must be values for students to hold on to carry out their emancipatory will and actions. That is, to lift up the dignity and the value of the underrepresented and unheard member of society by psychology itself. At these points, lies the urgency of this study. This is an explorative study to uncover the social representation of psychology student's perception towards the role of psychology in creating social changes.

\section{Methods}

\subsection{Participants and Design}

Participants were 104 psychology students (28 males, 76 females; 101 undergraduate, 3 graduate students). There were $68 \%$ students aged 19 - 22, and $32 \%$ aged 23 - 25 years old. Sixty-three percent of the participants went to college from 2009-2012, while 37\% of them went to college from 2013-2016. Majority of psychology $(n=74)$ students came from Jakarta, the capital of Indonesia (Bina Nusantara University, Persada Indonesia Y.A.I. University, and Atma Jaya Catholic University of Indonesia). The rest $(n=30)$ came from Banten and West Java (Pelita Harapan University, Padjadjaran University, and Maranatha Christian University) as well as Central Java (Satya Wacana Christian University). A participant can give more than one response.

The design of this present study is qualitative-descriptive exploratory.

\subsection{Instrument and Procedure}

To know how students refer to psychology curriculum in representing ideas of social changes, the authors analyzed three topics: First, their perception of social changes initiated by psychology; Second, the urgent social problems in Indonesia that need to be solved; and finally, how psychology curriculum in Indonesia could be improved to facilitate social changes.

Responses were obtained by asking the participants to fill out 13-items openended questionnaire revolving around the three topics mentioned. Sample questions are "How can Psychology facilitate social changes?", "According to you, what can be improved on the current Psychology curriculum to initiate social 
changes?", and "Can you give example(s) of concrete approach from a standpoint of Psychology that can be used to solve current social problems?"

Participants' responses were read repeatedly until units of meaning were found. These units of meanings were then quantified, by first, they were phrases-coded into categories, depending on how many kinds of answers there were, and secondly, frequencies of answers that appeared in the category were then accounted in the analysis. All responses were attempted to fit into one or more categories, or in other words, until a saturation in the data processing was achieved.

\section{Results}

Below we present the result of each question we asked participants, and discuss them based on their respective category.

\section{1. "What Drives You to Choose Psychology as a Major?"}

The majority of participants (62 out of 111 unique responses) were curious or think that the science behind Psychology is very interesting. To them, Psychology is "abstract and alien" study that deals with the mind. From what they have learned in the classroom which mostly introduces mainstream Psychology, these answers are to be expected. Exposure towards mainstream Psychology provides novel ideas of what Psychology are to the eyes of the learner.

The more pragmatic reason comes from another group of responses. Twenty-three out of 111 responses indicated that participants chose Psychology due to its good prospect in the future, as psychology provides skills that can be used in various industries. The third largest responses (18 out of 111) lean to the humanistic side of Psychology, as they chose Psychology in order to learn about, understand, and finally help and make a change in other's life. While the rest (8 out of 111) learned Psychology to better understand themselves in terms of self-concept, interpersonal dan intrapersonal relation, daily decision making, and selfregulations.

\section{2. "Who Is Your Role Model, and Why?"}

More than half of the participants (102 out of 187 unique responses) had politicians as their role models. They claimed that politicians like the President, Jakarta's Governor, and Bandung's Mayor are good examples of righteous leaders.

Second largest responses fall (38 out of 187) in the category or inspirational figures. These are the people that revolutionized how people see things or people in the society that inspired many others to achieve great things, for example, Martin Luther King, Anderson Cooper, and various musicians.

Meanwhile, pacifist and religious figures like the Pope, Mother Theresa, and Gandhi took the third place, along with Scientist/Educator category, with 21 responses each. The rest ( 5 out of 187 responses) answered their parents or related kin as their role model. 


\section{3. "What Does Social Change Mean to You? What Are the Examples?"}

Most participants (45 out of 112 unique responses) agreed that social changes imply progressive movement towards a better society. This means, people are being educated, more tolerable each other, and strive to resolve urgent social and environmental problems.

For other participants (26 out of 112), social change is simply the shift or the movement of society to be different in a direction, without necessarily good or bad (up to debate). For the same number of responses, participants also thought that social changes occur in the mind of society. The more open, empirical, and critical the society towards certain issue the more social changes there will be.

For the last category (15 out of 117), responses were more specific and perhaps the most compelling, as participants concluded that increasing tolerance and harmony among society members are the mean of social change.

\section{4. "What Kinds of Social Changes Would You Like to Engage in?"}

The most popular social changes ( 30 out of 126 unique responses) participants wanted to initiate are the awareness of the problems of children and education in Indonesia. Education privileges, morality, and the environment for children and teenager to grow are very important factors that society sometimes neglects.

Twenty-six out of 126 response recorded from participants indicated that they wanted to see changes in lifestyle, cultural norms, and the environment that people live in. For example, the preservation of traditional culture in the era of globalization, or tackling the problem of traffic or flood.

Next (19 out of 126), participants wanted to see changes in the social gap between society members. There should be less distance between the wealthy/urban and the poor/rural in terms of welfare, well-being, and social services provided.

Seventeen out of 126 responses indicated that participants wanted to change how the current society thinks, and unite them initiate positive changes.

Fourteen out of 126 responses were lean towards the openness of the society to marginalized groups, for example, the LGBT (lesbian, gay, bisexual, and transgender) community and the disabled. The rest did not specify.

\section{5. "Does Psychology Support Social Changes?"}

Participants (49 out of 122 unique responses) in general answered yes. The rest were divided into several groups of the reason why Psychology supports social change. Nineteen out of 122 responses stated Psychology does heavily support social changes as it promotes progressive changes in terms of social behaviors, cognition, and attitude towards problems in society.

Fourteen out of 122 responses indicated that Psychology does support, but not directly as it depends on who is enforcing the science, how people absorb the true essence of change, and the resistance among members of change target. The same number also indicated agreement due to the nature and the way of psy- 
chological science is designed to help others. Lastly, 11 out of 126 answers indicated that psychology provides the essence of humanity, and by default supports the social changes.

\section{6. "How Can Psychology Facilitate Social Changes?"}

Most of the participants (44 out of 122 unique responses) agreed that Psychology facilitates social changes through its sophisticated theory and method in defining, identifying, and solving social problems. Thirty out of 122 participants agreed that Psychology promotes awareness and help people to think and see through the real problems to overcome. The third group (28) stated that Psychology could change how people think and behave.

The fourth largest groups (11 out of 122) answered Psychology can serve as a bridge to bring people together, regardless of social groups. Finally, Psychology can inspire and motivate an individual to put an impact and change the society of his/her own accord.

\section{7. "What Are the Psychology Subject(s) that Support Social Changes?"}

The one with the most answer is Social Psychology/Social Intervention (98 out of 256 unique responses), followed by Personality Psychology (42), Education/ Learning Psychology (38), Developmental Science (23), Industrial/Organizational Psychology (20), Cognitive Psychology/Creativity and Philosophy (12 each) and General Psychology (11).

\section{8. "Can You Give Example(s) of Concrete Approach from a Stand Point of Psychology that Can Be Used to Solve Current Social Problem?"}

The majority ( 35 out of 123 unique responses) of the answer fell into the category of practicality that sees Psychological science can be channeled through educational programs like socializations, seminar, workshop that are actively engaging with the target community's problems. Second largest group (22 out of 123) answered to change themselves in order to provide more progressive benefits for the surrounding environment.

The third largest group (19 out of 123) answered differently, stating Psychology should directly approach and change the mindset of the people in order to solve problems. The fourth group (17 out of 123) provided more practical answers, like helping to educate and help the children of the unfortunate to have access to better life and education. Finally, 11 out of 123 stated that there should be a new breakthrough that specifically targets social problems, while the rest answers were unspecified.

\section{9. "Does Psychology Curriculum Support Excommunication of Certain Social Groups?"}

The majority of the participants (46 out of 111 unique responses) answered 
"No". The second largest group (27 out of 111) stated that psychology, oppositely, promotes tolerance between communities. The third largest group (25 out of 111) answered Psychology provides education and the information of what will happen, thus declaring the motive of excommunication.

Surprisingly, 13 out of 111 agreed that Psychology, in the "wrong hands", does promote excommunication.

\subsection{0. "What Are the Urgent Social Problems that Need to Be Tackled by Psychology?"}

The majority (33 out of 159 unique responses) answered that the most urgent problems are children-related rights or education. This is seconded by the justice of economy and welfare of the poor and secluded (22 out of 159), followed by the close-mindedness of the current society, high crime rate (19 out of 159), mental health (17 out 159), social norm and the environmental problem (17 out of 159), marginalization of certain members of society, and human rights problem (both 15 out of 159).

\subsection{1. "What Are the Psychological Theories that You Know Can Facilitate or Support Social Changes?"}

Most participants (36 out 115 unique responses) did not provide specific comments on this answer. Followed by various Social Psychology related theory (21 out of 115), Social Learning Theory and Psychoanalysis related theory (both 13 out of 115), Positive/Humanistic related theory (12), and finally, Behaviorism and Cognitive-related theory (both 10 out of 15).

\subsection{2. "What Needs to Be Improved from Psychology Curriculum to Initiate Social Changes?"}

Astounding 78 out of 99 unique responses agreed that curriculum should include more practical lessons like field study, observation, interactive learning, and real-life case study. The second largest group (7 out of 99) asked to study more critical and in-depth theory related to Psychological Science.

Finally, 3 out of 99 answered that it depends on how the subjects are presented. The rest did not provide any comments on this question.

\subsection{3. "What Are the Social Changes that You Want to Initiate in the Future?"}

The majority of the participants ( 32 out of 121 unique responses) answered that they wanted to increase the awareness of mental health problems in Indonesia. Second largest group (24 out of 159) answered that they wanted to improve and make innovations regarding the education system and child-related welfare problems.

Fifteen out of 121 wanted to bring down the problems of tolerance among social groups and community in Indonesia. Twelve answered problems regarding the environment and social norm related problems. Eight answered that they 
wanted to fight for women's right, and the rest did not provide specific comments.

\section{Discussion}

The majority of participants' responses stating "curiosity about the mind" as the driving force behind choosing psychology as a study major indicates that there is a need to interpret and explain the behavior and psychological conditions of self and others. This driving force is not social-emancipatory, rather "egotistic" one. Reinforcing the motive, in second place, the answer that leans more to career prospect is more pragmatic and related to their normative development task that they should carry out on their age.

Only a small portion, less than $50 \%$ of participants, stated that other people's life is their main concern (top of mind) in studying psychology. This shows that the bigger picture of the social contribution of psychology is not yet dominating the minds of psychology students, even though the social role of psychology scholars are very much needed, as they gain more media coverage and getting more expansive, for example, being the part of amicus curiae in child marriage law passing [12]. It seems that socialization about critical social psychology is homework for the community of psychology to ensure it become one of the utmost important and significant motives to learn about psychology.

What is interesting here is the political figures that become the participant's main role models. This serves as a great potential to learn more about and practice critical psychology, as it can become more effective when it comes to discussing political and public policies. However, the problem in Indonesia is similar to South Africa; the psychology uses approaches that "hid(e) politics ... (with) value-free and scientific way" [13] (p. 214). The theory of critical psychology is only being introduced systematically in the Master's level, at least only in a few universities, e.g. Universitas Indonesia and Atma Jaya Catholic University of Indonesia, in Jakarta. We can predict that the participants have not been exposed sufficiently about the framework to integrate psychology with politics, despite their role models are politicians.

We found the keywords like "minimalizing social gap" and "uniting people from different social levels and groups in a small number" were in the minority of participants' responses. The majority of the answers were more limited and generalistic in their narration like "using psychological theory and method to combat the social issue and change people," meanwhile, its realization would be much more dynamic in the field. There were not many empathetic answers or attention paid to the underrepresented members of the society, except the response of striving for "openness of the society to marginalized group, e.g. the LGBT community and the disabled". We noticed that the key words of "alienated", "oppressed", "the poorest", "politically harmed", "inequality", "injustice", "structurally suppressed", and "marginalized" were not quite popular among psychology students in Java, Indonesia. Meanwhile, poverty and religious 
and racial nuanced conflict are the social issues that flare up and dominant in Indonesia. This also shows that the awareness of psychology students about the reality of social classes or hierarchies, as well as constellation of power that often brings forth victims (that should be taken care of by psychology), is still at a minimum level.

Regarding their aim of social change, participants in the majority answered "Mental Health Promotion" as their main objective. This is one of the best possible answers that we could get, as it is often hoped from the students to initiate themselves in engaging and recognizing the problem of mental health in Indonesia. Also, in Indonesia, psychology is close to the medical and health world, even the founder of the first psychological education in Indonesia is a psychiatrist, namely Prof. Dr. Slamet Iman Santoso [14]. In addition to this response, while the urgent social problems in their eyes lie in the educational and children life field, when we linked with the answer "change the self, change the mindset" they give to the question of "Concrete Approach from a Stand Point of Psychology", it appears that the psychology students in Java consistently mainly, if not the singly, remember individual or interpersonal approach as the approaches to solve social problems. However, mental health and educational fate are still not yet seen as products of socio-political-cultural forces that operate in a society [15] [16].

In responding to the question of the psychological subject that drives social changes, Social Psychology/Social Intervention was agreed among participants to be the most relevant subject. However, participants still thought the popular channel to advocate its theory and practice is through educative programs like seminars and workshop. This finding is different from the standpoint of critical social psychology, stating that social changes occur in the historicity from the community's activities. This means all of the theories and practices need to be blended and embodied in the communal process, and not to be presented formally and incidentally or short-period from an external agent that is considered authoritative in nature. It is not surprising that Sinha [16] (p. 65-66) expressed her criticism:

"We should also see why psychology is related to everyone's life on the humanitarian ground $[\ldots]$. As social psychologists, we mostly belong to middle class educated background. However, the reality is different for them and the scientific methods which were available very much corresponding to the limitations of the boundaries of their experiential realities. So, the effort on the part of social scientists was to infuse into the existing social structure, the new way of life (from Western culture) and thoughts in order to transform the members and at the same time preserving the basic structure of the society."

At this point, an idea of Teo [17] about deconstruction-reconstruction-construction methods as a base of Social Psychology becomes very relevant. If the majority of the participants in the present study stated that field study, observation, interaction learning, and real-life case study need to be increased in the 
curriculum, then the soul of each method should be the spirit of deconstruction-reconstruction-construction. With deconstruction, psychology academics present facts about the existence of discriminative or colonized practices in the society. Through reconstruction, they re-build the logic and the method of psychology based on the deconstruction made earlier. Finally, through construction, they show the limitation of psychological researches and theories and provide new tools and perspective to inspire better understanding and action towards the social issue in the society. This method can challenge the "status quo" in the current society, and in turn becomes the concrete operationalization of "defining, identifying, and solving social problems" among the participants toward the question of "How can Psychology facilitate social changes?"

\section{Conclusions, Limitation, and Recommendation}

Based on participant's consensual key words responses and from the discussion, we can conclude about the social representations of Indonesia's psychology student towards the role of psychological science in the prevailing social issues, i.e. they have not yet weightily realized or incorporated the concept of "hegemonic psychological science" cf. [15] (p. 222) or "meta-colonialism" cf. [15] (p. 221) in the psychological field that they learn in the university. Borrowing the term "naïve realism", participants in this study tend to fully accept without being critical of the existing psychological concepts and theories and view them as the natural standard on how they will come up with idea and motivation to initiate a social change. The implication is that their learning and study on the history of psychology has not yet saliently been influenced by the sense and intention of decolonization and emancipatory urgency, as endorsed by critical psychology.

Due to the reasons mentioned, this study strongly suggests study programs of psychology in Indonesia to do a major revision of the psychology curriculum, in terms of 1) sharpening the identification of social problem in Indonesia, the characteristic of Indonesian Psychology, and the belief in Indonesia's social strength; 2) incorporating the element of the historicity of the knowledge, wisdom, and the behavior of the society, as well as the politics of Indonesia in the content of study; 3) advocate critical and transformative pedagogies for teaching and learning; 4) sustainably collaborate with communities to reflect, deconstruct, reconstruct, and construct the psychological concepts and theory learned; and finally; 5) integrate and strengthen the interdisciplinary work between psychology and other sciences. The work of Watkins and Ciofalo [18] could be used as a reference.

The limitation of this study is that there has not been a comprehensive mapping that relates participants' backgrounds (economic status, religious orientation, cultural background of parents, past family experience as "victims of development"-if any, as well as membership and activity in extracurricular organizations) to his/her opinions on psychology and social change. Such backgrounds might interact uniquely with the education he/she undergoes in the Psychology Department in influencing his/her view of the role of psychology in initiating 
and facilitating social change. Further research could increase the number of participants while overcoming those limitations.

Subsequent study is also suggested to test the hypothesis proposed by Supratiknya [19] that the perspective of critical psychology-for requiring an interdisciplinary approach-fits more into the knowledge basis for developing curriculum at the Doctoral level. Testing is needed because Doctoral education in Indonesia is expected to build a new theoretical proposition that is potentially published in mainstream journals, while mainstream psychology journals do not provide an extensive opportunity for critical-hermeneutical-deconstructive focused publications that characterize critical psychology. No wonder if Fox [20] observed, "Some psychologists who do come across critical psychology are sympathetic to its goals but don't think it's smart career move when trying to get academic jobs." However, emerged questions are: How to cultivate more than just sympathy to critical psychology among psychology doctoral students? Would it not be too late if the terms itself was known at the time of the doctoral course? Or, in contrast, would it be better for a university to "sprinkle" critical psychology since the Bachelor level, then socialize sustainably the philosophical roots at the Master level, and endorse putting into practice the embodiment of critical psychology on all research (both quantitative and qualitative) activities at the Doctoral level, with certain orientation that he/she could live it even in everyday's business until the next (post-doctor) life phases?

Furthermore, might it be best if on Bachelor of Psychology level, the university advocates the students to participate in subjects that intersect with critical psychology? This optimism is based on two considerations, 1) The California Institute of Integral Studies has become a model by holding a minor in critical psychology program [21] containing subjects such as Social Change, Restorative Justice, Dialogue \& Community Development, and Global Studies; 2) Undergraduate Programs at the non-Psychology Department, such as Sociology and Anthropology, at the Faculty of Social Sciences in Indonesia have provided courses related to critical psychology such as a) Social Gaps and Exclusion, b) Social Change, c) Social Identity and Global Dynamics, d) Political Sociology, e) Social Inequality and Poverty, f) Development and Underdevelopment, g) Power in Medical World [22] [23], h) Anthropology of Globalization, i) Political Anthropology, j) Community Empowerment Studies as well as k) Studies of Body, Reasoning, and Society [24] [25]. This indicates that the capacity of undergraduate students to digest current political issues and interdisciplinary approaches is adequate, and in the context of Indonesia, which is thick with various social problems, critical psychology is very potential to become mainstream. Those matters need to be addressed in action research that follows up on the results of this study.

\section{Acknowledgements}

We thank Dr. Yosef Dedy Pradipto of Psychology Department, Bina Nusantara 
University, who assisted us in data collecting stage of this study. We also gratefully acknowledge the Mathematics, Science, and Computer Science Education International Seminar (MSCEIS 2016) Committee's support which gave us the opportunity to present our early idea of this study and to sharpen it based on the inputs obtained from the scientific community at Universitas Pendidikan Indonesia, Bandung, West Java.

\section{References}

[1] Cruz, M.R. and Sonn, C. (2010) (De)colonizing Culture in Community Psychology: Reflections from Critical Social Science. American Journal of Community Psychology, 47, 203-214. https://doi.org/10.1007/978-1-4939-1283-4_10

[2] Lasmono, H.K. and Siaputra, I. (2016) Pengayaan Pendidikan Psikologi Indonesia: Penguatan Tata Nilai Ke-Indonesia-an Sebagai Modal Dasar Pencapaian Indonesia Emas (Enrichment of Indonesian Psychology Education: Strengthening Indonesian Values as the Basic Capital of Achieving Golden Indonesia).

http://ap2tpi.or.id/index.php?option=com_k2\&view=item\&task=download\&id=104

[3] Yusainy, C.A. (2015) Quo Vadis Psikologi Sebagai Sebuah Kajian Ilmiah? Buletin Psikologi, 23, 51-56.

http://jurnal.ugm.ac.id/index.php/buletinpsikologi/article/download/10577/7972

[4] Teo, T. (2005) The Critique of Psychology: From Kant to Postcolonial Theory. Springer Science + Business Media, Inc., New York.

[5] Kuwado, F.J. (2012) Psikolog Buka Hotline bagi Keluarga Sukhoi (Indonesian Psychologist Opens Hotline for Sukhoi Crash Victims' Family).

http://news.kompas.com/read/2012/05/14/13370663/psikolog.buka.hotline.bagi.kel uarga.sukhoi

[6] Suharto, J.P. (2012) Dimana dan Sedang Apa? (Where and What Were You Doing?) at Psikologi Indonesia Mailing List.

https:/groups.yahoo.com/neo/groups/psiindonesia/conversations/messages/19381

[7] Koentjoro, K. (2012) Draft Prosedur Operasi Baku-Bencana (Standard Operation Procedure Draft-Disaster) (SOP) at Psikologi Indonesia Mailing List. https://groups.yahoo.com/neo/groups/psiindonesia/conversations/messages/19727

[8] Tomaneng, R. (2015) Recovering Kapwa: Filipino American Postcolonial Psychology as Decolonizing Praxis. Multicultural Perspectives, 17, 164-169. https://doi.org/10.1080/15210960.2015.1053327

[9] Abraham, J. and Rufaedah, A. (2014) "Theologization" of Psychology and "Psychologization" of Religion: How Do Psychology and Religion Supposedly Contribute to Prevent and Overcome Social Conflicts? Procedia Environmental Sciences, 20, 516525.

[10] Parker, I. (2015) Handbook of Critical Psychology. Routledge, New York.

[11] Fox, D., Prilleltensky, I. and Austin, S. (2009) Critical Psychology: An Introduction. Sage Publications Ltd., London.

[12] Sahbani, A. (2014) Amicus Curiae untuk Pengujian UU Perkawinan (Amicus Curiae for Examination of Marriage Act).

http://www.hukumonline.com/berita/baca/lt5492765e30325/iamicus-curiae-i-untuk -pengujian-uu-perkawinan

[13] Painter, D., Terre Blanche, M. and Henderson, J. (2006) Critical Psychology in South Africa: Histories, Themes and Prospects. Annual Review of Critical Psychol- 
ogy, 5, 212-235.

[14] Sarwono, S.W. (2013) An Indonesian Perspective on Psychological Literacy. In: Cranney, J. and Dunn, D.S., Eds., The Psychologically Literate Citizen: Foundations and Global Perspectives, Oxford University Press, Oxford, 178-190.

[15] Adams, G., Dobles, I., Gómez, L.H., Kurtiş, T. and Molina, L.E. (2015) Decolonizing Psychological Science: Introduction to the Special Thematic Section. Journal of Social and Political Psychology, 3, 213-228. https://doi.org/10.5964/jspp.v3i1.564

[16] Sinha, C. (2016) Decolonizing Social Psychology in India: Exploring Its Role as Emancipatory Social Science. Psychology \& Society: Online Journal, 8, 57-74.

[17] Teo, T. (1999) Methodologies of Critical Psychology: Illustrations from the Field of Racism. Annual Review of Critical Psychology, 1, 119-134.

[18] Watkins, M. and Ciofalo, N. (2011) Creating and Sharing Critical Community Psychology Curriculum for the 21st Century: An Invitation. Global Journal of Community Psychology Practice, 2, 9-18.

[19] Supratiknya, A. (2016) Menegaskan Kedudukan Psikologi Sebagai Ilmu \& Implikasinya Terhadap Kurikulum Program Pendidikan Akademik Psikologi Pada Jenjang S1, S2, \& S3 di Tanah Air (Affirming the Position of Psychology as a Science \& Its Implication to Curriculum of Academic Program of Psychology at Bachelor, Master, \& Doctoral Level in Indonesia). The National Scientific Meeting of Indonesian Psychological Association with Theme "Menelisik Perkembangan Psikologi Indonesia" ("Investigating the Development of Psychology in Indonesia"), Yogyakarta, 18-19 November 2016.

[20] Fox, D. (2011) Frequently Asked Questions-Critical Psychology. http://www.dennisfox.net/faq.html

[21] California Institute of Integral Studies (2017) Minor in Critical Psychology. https://www.ciis.edu/academics/bachelors-completion-program/minor-in-critical-p sychology

[22] Departemen Sosiologi (2017) Mata Kuliah-Sarjana. http://sosiologi.fisip.ui.ac.id/mata-kuliah/

[23] Departemen Sosiologi (2013) Mata Kuliah Sosiologi S1. http://sosiologi.fisipol.ugm.ac.id/main/wp-content/uploads/2013/11/Mata-Kuliah-S osiologi-S1.pdf

[24] Departemen Antropologi (2017) Kurikulum. http://antropologi.fib.ugm.ac.id/akademik/kurikulum

[25] Departemen Antropologi (2017) Kurikulum Program Sarjana Antropologi. http://anthropology.ui.ac.id/program_studi.html 
Submit or recommend next manuscript to SCIRP and we will provide best service for you:

Accepting pre-submission inquiries through Email, Facebook, LinkedIn, Twitter, etc. A wide selection of journals (inclusive of 9 subjects, more than 200 journals)

Providing 24-hour high-quality service

User-friendly online submission system

Fair and swift peer-review system

Efficient typesetting and proofreading procedure

Display of the result of downloads and visits, as well as the number of cited articles Maximum dissemination of your research work

Submit your manuscript at: http://papersubmission.scirp.org/

Or contact jss@scirp.org 